\title{
Socialtjänstens organisation som forskningsobjekt
}

\author{
STAFFAN JOHANSSON
}

Artikeln baseras på en översikt av avhandlingar, vetenskapliga artiklar och en del annan uppmärksammad forskning som är publicerad mellan 1990 och 2000 och vill ge en överblick över forskningen om den svenska socialtjänsten som organisation. Den visar på forskningsresultat om organisationens och regiformens betydelse för utförandet av socialtjänstverksamhet samt identifierar områden för fortsatt forskning.

\section{Välfärdsforskningens vita fläck?}

Den sociala välfärden är fundamental i varje samhälle. "Vård, skola, omsorg" är paroller som står högt på de flesta partiers program, och medborgarna reagerar starkt när otillräckligheter eller kvalitetsbrister uppenbaras i välfärdspolitikens faktiska resultat. I förädlingskedjan mellan välfärdspolitiken och dess faktiska utfall finns välfärdssektorns organisationer. Som framhållits av t.ex. Rothstein $(1991,2003)$ är dessa

Staffan Johansson är docent i offentlig förvaltning och universitetslektor vid Förvalningshögskolan, Göteborgs universitet. organisationer av central betydelse för ett modernt samhälles funktionssätt och för tilltron till demokratin, men är trots detta ofta utelämnade vid analys av välfärdspolitiken. Utformningen av den offentliga förvaltningen - förvaltningspolitiken - bör emellertid inte ses som en praktisk konsekvens av genomförda politiska program. Det är lika rimligt att vända på perspektivet och betrakta förvaltningsstrukturen som en vid varje tidpunkt given restriktion för vilken välfärdspolitik och vilka reformer som kan genomföras. I vissa analyser (t.ex. Evans et al. 1985) är förvaltningsstrukturen viktigare än både politiska partier och sociala strukturer för länders politiska utveckling.

Det finns skäl att anta att kunskaps- 
bildningen om välfärdssektorns organisationer inte har givits den prioritet den förtjänar. Inom politik och förvaltning visar sig bristande kunskaper i att styroch organisationsformer som är ämnade för affärsdrivande företag införs trots att förutsättningar saknas; Sverige anses vara ett av de länder som i högst grad tagit till sig det marknads- och företagsorienterade reformpaket som i internationell litteratur går under benämningen New Public Management (Hood 1995). Enligt sociologen Roine Johansson (1998) ägnar sig forskarna i första hand àt inflödet (politiken) och utflödet (medborgarnas uppfattningar) av välfärdspolitiken, och i mindre grad åt vad som sker i den "svarta lådan" däremellan. Papakostas (1999) anser att det finns förvånande lite forskning om välfärdsstatens organisationer och att många misstag avseende administrativa reformer som begåtts kunde ha undvikits om det funnits en kritisk massa av forskare inom området.

Välfärdssektorns organisationer tycks alltså vara ett angeläget men eftersatt forskningsområde. Detta är paradoxalt eftersom organisationsteorin utvecklats starkt under de senaste decennierna, inte minst genom internationell empirisk forskning om välfärdssektorns organisationer. Det är inte osannolikt att såväl demokrati som effektivitet skulle kunna öka väsentligt om den offentliga förvaltningen organiserades på ett mer ändamålsenligt sätt. Det kan därför vara på sin plats att försiktigt inleda ett kunskapssökande med att avgränsa uppgiften till ett speciellt verksamhetsområde, socialtjänsten, och söka få överblick över den forskning som redan finns.

Syftet med artikeln är att ge en överblick över kunskapsläget om den svenska socialtjänsten som organisation. Mer specifikt vill jag, i linje med temat för detta specialnummer av Socialvetenskaplig tidskrift, kasta ljus på vad forskningen har att säga om organisationens och regiformens betydelse för utförandet av socialtjänstverksamhet. Ett bisyfte med artikeln är att identifiera områden för fortsatt forskning om socialtjänsten som organisation.

Fortsättningen av artikeln är disponerad enligt följande: I nästföljande avsnitt presenteras några teoretiska aspekter på begreppet organisation. I det tredje avsnittet presenteras den forskningsöversikt som utgör det huvudsakliga empiriska underlaget för artikeln. I det fjärde avsnittet följer ett slags sammanfattning över vad svensk forskning har att säga om organisationsformens betydelse för utförandet av sociala tjänster och i det femte följer motsvarande beskrivning av regiformens betydelse för samma sak. Artikeln avslutas med några slutsatser och uppslag till angelägna framtida forskningsområden.

\section{Organisationer som forskningsobjekt}

Det finns nog en ganska stor enighet bland organisationsforskare om att organisationsteorins övergripande syfte är att förklara organisationsbeteende på individuell, strukturell eller ekologisk nivå; enigheten om vad som menas med en organisation är betydligt mindre. Den samhällsvetenskapliga organisationsforskningen har en kort men dynamisk historia. Fastän Taylor, Fayol och deras samtida utfört viktiga arbeten 
med stor normativ betydelse för praktiskt organisationskunnande, vill många sociologer (Scott 1991) datera uppkomsten av den teoretiskt orienterade organisationsforskningen till Webers klassiska arbeten där han gav generella förklaringar - i hans fall den historiskt belagda tendensen mot ökad modernitet och rationalitet inom samhället - till organisationers auktoritetsformer, strukturer och medlemmarnas beteende (Weber 1922/1983). Weber och de andra klassiska studierna knyter an till den ursprungliga betydelsen av organisation (det grekiska ordet organon som betyder verktyg) vilket innebär att organisationer ses som rationella system som uppvisar relativt formaliserade sociala strukturer och är inriktade mot specificerade mål (Scott 1991).

Bilden av organisationer som rationella system är inte orimlig, eftersom det är den bilden som ger dem legitimitet. Närstudier av vad som pågår i organisationer har dock fått många forskare att inse betydelsen av informella drag och svårigheten att konsekvent tillämpa rationalitet $\mathrm{i}$ beslutsfattande och planering. Human Relationsskolan (Roethlisberger \& Dickson 1943, Mayo 1945) gav därför en alternativ bild av organisationer som levande sociala system vars medlemmar har ett gemensamt intresse av systemets överlevnad och följaktligen engagerar sig i kollektiva aktiviteter i informella strukturer för att säkerställa detta mål (Scott 1991).

Oavsett om man ser organisationer som rationella eller som levande system har man det gemensamt att man har skurit bort studieobjekten från deras omgivningar. Forskare från sextiotalet och framåt började dock förstå att det var snarare förhållanden i omgivningen än interna mål och strategier som avgjorde strukturer och beteenden i organisationer, och kom att utveckla contingencyteori (Lawrence \& Lorsch 1967), resursberoendeteori (Pfeffer \& Salancik 1978) och nyinstitutionell organisationsteori (Meyer \& Rowan 1977, DiMaggio \& Powell 1991) som resultat av sin forskning. Åttio- och nittiotalens organisationsforskning har, åtminstone i Sverige, dominerats av nyinstitutionell teori som betonar att organisationer inte bara är tekniskt utan även institutionellt beroende av omgivningen. Organisationer bör alltså i linje härmed förstås som öppna system, bestående av koalitioner av varierande intressentgrupper som utvecklar mål genom förhandlingar. Koalitionens struktur, processer och resultat påverkas i hög grad av omgivningsfaktorer (Scott 1991).

Parallellt med den teoretiska utvecklingen har den empiriska organisationsforskningen fått en allt starkare ställning inom allt fler samhällsvetenskapliga discipliner. Företagsekonomiska forskare har särskilt intresserat sig för specialområden såsom ledarskap, styrmetoder och organisationsreformer, och svenska företagsekonomiska forskare har gjort viktiga bidrag inom den nyinstitutionella teoribildningen. Organisationsforskningen hade till en början en ganska svag ställning inom statsvetenskapen, eftersom dess fokus av tradition har gällt den politiska processen fram till beslutet; själva implementeringen sågs i regel som en ren expeditionsåtgärd. Synen på implementering kom dock att förändras från början av 1970-talet genom ett antal klassiska studier inom socialpolitikens 
område (t.ex. Pressman \& Wildavsky 1973, Lipsky 1980) som visade att de offentliga "gatuplansbyråkraterna" - socialarbetare, lärare, sjuksköterskor, läkare, poliser - har stor handlingsfrihet i sitt dagliga arbete, och att det är de snarare än politikerna och toppbyråkraterna som utformar politiken inom sitt område.

Organisationsforskningen har numera en stark ställning inom alla samhällsvetenskapliga discipliner. Orsaken till den dynamiska utvecklingen är sannolikt att inget akademiskt ämne har tillåtits få monopol på området, och att de aspekter på organisationer som lyfts fram - individer, grupper, genus, kultur, institutioner, ledarskap, lärande, kunskap, etcetera - har befruktat varandra. Den så framgångsrika nyinstitutionella organisationsforskningen har hämtat en stor del av sin empiri från välfärdssektorns organisationer (t.ex. skolan och socialvården), men har med stor framgång också kunnat användas för att förklara spridningen av managementkoncept och betydelsen av varumärken inom företagsvärlden (Meyer \& Rowan 1977, DiMaggio \& Powell 1991, Mizruchi \& Fein 1999). Den har också varit användbar vid analys av (misslyckade) organisationsreformer (Brunsson \& Olsen 1997) och förändringströghet inom professionella organisationer (Sahlin-Andersson 1994). Potentialen för organisationsteorin att hjälpa oss öka förståelsen för vad som händer i välfärdssektorns organisationer är betydande. Enligt Yeheskel Hasenfeld, en av de mer internationellt kända forskarna inom området, är resursberoendeteorin och den institutionella teorin särskilt användbara för att förklara organisationsbeteende inom välfärdssektorn (Hasenfeld 1992).

\section{Den svenska forskningens intresse för socialtjänsten som organisation}

Det huvudsakliga underlaget för uppsatsen är en forskningsöversikt med benämningen "Socialtjänsten som organisation" (Johansson 2002) som är utförd på uppdrag av Socialstyrelsen. Tillvägagångssättet vid urvalet beskrivs utförligt i översikten (Johansson 2002), men rent allmänt kan sägas att den innefattar svenska samhällsvetenskapliga avhandlingar, tidskriftsartiklar på svenska som utsatts för vetenskaplig kvalitetsgranskning samt viss övrig uppmärksammad forskning som berör socialtjänstens organisation. Avgränsningen till svenskspråkiga tidskriftsartiklar gjordes främst för att ursprungstexterna i linje med översiktens syfte ska vara lätt tillgängliga för personer utanför vetenskapssamhället. För samtliga forskningstexter gäller att de ska vara publicerade mellan 1990 och 2000 Forskning som har publicerats därefter ingår alltså inte.

Det finns skäl att betona att avgörandet av vilka rapporter som behandlar organisationsfrågor inte var alldeles enkelt. Gränsen mellan vad som är en behandlings- eller utredningsmetod inom socialt arbete och vad som är ett organisatorisk-strukturellt fenomen är inte självklar. I det praktiska urvalsarbetet vägde författarnas egna bedömningar tungt. Om organisationsfenomen haft central betydelse som variabel i studiernas huvud- eller bisyfte, eller som viktig slutsats, har de inkluderats i översikten. I Tabell 1 nedan ges en översikt av ämnestillhörigheten för de studier som presenteras i forskningsöversikten. 


\section{Vilka forskar om socialtjänsten som organisation?}

Som väntat dominerar forskare från ämnet socialt arbete i översikten; de står för ca hälften av samtliga referenser. Bland avhandlingarna i socialt arbete är det få som har en renodlad organisationsteoretisk referensram, men några (t.ex. Szebehely 1995, Blom 1998, Levin 1998) har för organisationsteorin centrala problemställningar. De flesta avhandlingar och övriga publikationer inom socialt arbete som ingår i översikten är inriktade på att förstå eller förklara det sociala arbetet och dess metoders inneboende karaktär, förutsättningar, förändringar och resultat, och där är organisatoriska förutsättningar oberoende variabler bland flera andra. De flesta avhandlingarna har sina viktigaste teoretiska referenser utanför organisationsteorin, t.ex. handlingsteori, teorier om lärande, professionaliseringsteori, maktteori, genusteori m.fl. Ungefär en fjärdedel av avhandling- arna knyter an till gängse organisationsteoretiska referenser, ännu fler knyter an till det beskrivningsspråk som i internationell forskning tillämpas på s.k. street level bureacracies (Lipsky 1980) och Human Service Organizations (Hasenfeld 1983, 1992). Ett ytterligare kännetecken för avhandlingarna inom socialt arbete är att de nästan undantagslöst behandlar någon eller några verksamhetsområden inom socialtjänsten (t.ex. äldreomsorg eller individ- och familjeomsorg) och bara i något enstaka fall studerar socialtjänstens verksamhetsområde samlat.

I en påfallande stor andel av avhandlingarna tycks insikten om organisationsspecifika fenomens betydelse för det sociala arbetet vuxit under studiernas gång. I flera studier som har studerat klientrelationer, förändringsarbete eller metodutveckling, var kopplingarna till organisatoriska variabler till en början svag, men stark när det gäller att förklara resultatet. Denna observation antyder att organisatoriska fenomen är underskattade som förklaringsvariabler inom ämnet socialt arbete. Den vanligaste

\section{Tabell I.}

Innehållet i forskningsöversikten fördelat på akademiska discipliner.

\begin{tabular}{lcccc}
\hline & Avhandlingar & Artiklar & Övriga texter & Summa \\
\hline Socialt arbete & 24 & 6 & 16 & 46 \\
\hline Företagsekonomi & 8 & 4 & 4 & 16 \\
\hline Sociologi & 6 & 1 & 5 & 12 \\
Statsvetenskap & 2 & 3 & 2 & 7 \\
$\begin{array}{l}\text { Övriga ämnen samt } \\
\text { Ospecificerat }\end{array}$ & 7 & 1 & 13 & 21 \\
\hline Summa & $\mathbf{4 7}$ & $\mathbf{1 5}$ & $\mathbf{4 0}$ & $\mathbf{1 0 2}$
\end{tabular}


metoden för datainsamling är fallstudier med intervjuer, men enkätundersökningar används också ganska frekvent.

Företagsekonomi kommer på andra plats i antalet referenser. Tre avhandlingar behandlar organisationsreformer, två villkor för ledarskap inom den "mjuka» sektorn, och en rör villkor för kunskapsutveckling inom olika regiformer. Företagsekonomerna har i regel ett något annorlunda fokus på socialtjänsten än kollegorna från socialt arbete; de förstnämnda verkar vara mer intresserade av socialtjänsten som organisationsfenomen och mindre för dess specifika verksamhet. Svenska företagsekonomer brukar vara intresserade av organisationsreformer och ledarskapsfrågor, och empirin från dessa studier hämtas ofta av accesskäl från offentliga organisationer. En stor andel av de företagsekonomiska studierna knyter an till nyinstitutionell organisationsteori och den använda metoden är fallstudier. Övriga studier visar upp en brokig uppsättning av teman, teorier och metoder.

Sociologins intresse för socialtjänsten är naturlig genom ämnets traditionella intresse för både välfärdssociologi och arbetssociologi. Trots detta innehåller genomgången endast fem avhandlingar med koppling till socialtjänsten som organisation och endast en (Nordström 1998) som har ett tydligt organisationsteoretiskt perspektiv. De övriga intresserar sig för ledarskapsproblem, kvalitetsfrågor och sociala rörelser. Såväl teorikopplingar som metoder för datainsamling visar upp ett brett spektrum.

Två statsvetenskapliga avhandlingar behandlar organisationsfrågor med empiri från socialtjänstens verksamhetsfält. Ingen av dessa har ett organisationsteoretiskt perspektiv; en behandlar förvaltningsetik bland hemtjänstassistenter (Gynnerstedt 1993) och en annan rör kommunala organisationsmodellers betydelse för jämställdhet i det oavlönade omsorgsarbetet i hemmen (Johansson 1997). Några statsvetenskapliga forskningstexter tar upp principiella problem med anknytning till privatisering och kundvalsmodeller inom t.ex. äldreomsorgen. Kvalitativa och kvantitativa datainsamlingsmetoder förefaller vara ungefär lika vanliga bland statsvetarna.

I gruppen övriga finns företrädare för ämnena pedagogik, psykologi, kulturgeografi, teologi, folkhälso- och vårdvetenskap, arbetsvetenskap samt för diverse temainstitutioner. De tar upp så skilda problemställningar som förändringsarbete, lärande, hemlöshet, ledarskap och etik, men med gemensam nämnare att de hämtat sin empiri från socialtjänstens verksamhetsområde. Även här visar valen av teori och metod upp ett brett spektrum.

\section{Vad handlar forskningen om?}

Studieobjekten kan antingen beskrivas i termer av verksamhetsområden eller organisationsaspekter. Flest referenser i forskningsöversikten berör äldre- och handikappomsorgen. Siffran för äldreomsorgen blåses upp en aning av några antologier som ingår i forskningsöversikten och som innehåller flera referenser, men även om man bara räknar antalet avhandlingar så finns flest som rör äldre- och handikappomsorgen. Antalet texter och särskilt antalet avhandlingar som rör ideella och andra ickeoffentliga organisationer är också oväntat 
Tabell 2.

Innehållet i forskningsöversikten fördelat på socialtjänstens verksamhetsområden.

\begin{tabular}{lcccc}
\hline & Avhandlingar & Artiklar & Övriga texter & Summa \\
\hline $\begin{array}{l}\text { Äldre- och handikap- } \\
\text { pomsorg }\end{array}$ & 17 & 8 & 18 & 43 \\
$\begin{array}{l}\text { Individ- och familjeom- } \\
\text { sorg }\end{array}$ & 12 & 1 & 5 & 18 \\
$\begin{array}{l}\text { Ideella och andra icke } \\
\text { offentliga organisationer }\end{array}$ & 7 & 4 & 2 & 13 \\
\hline $\begin{array}{l}\text { Övergripande organisa- } \\
\text { tionsfrågor }\end{array}$ & 11 & 2 & 15 & 28 \\
\hline Summa & $\mathbf{4 7}$ & $\mathbf{1 5}$ & $\mathbf{4 0}$ & $\mathbf{1 0 2}$
\end{tabular}

Tabell 3.

Innehållet i forskningsöversikten fördelat på organisationsaspekter.

\begin{tabular}{|c|c|c|c|c|}
\hline & Avhandlingar & Artiklar & Övriga texter & Summa \\
\hline $\begin{array}{l}\text { Formella strukturer och } \\
\text { dess effekter }\end{array}$ & 20 & 6 & 16 & 42 \\
\hline $\begin{array}{l}\text { Arbetsvillkor och lokala } \\
\text { organiseringsprocesser }\end{array}$ & 15 & 2 & 17 & 34 \\
\hline $\begin{array}{l}\text { Organisationsreformerl } \\
\text { verksamhetsutveckling }\end{array}$ & 9 & 6 & 17 & 32 \\
\hline $\begin{array}{l}\text { Olika organisations-/ } \\
\text { associationsformer }\end{array}$ & 8 & 8 & 6 & 22 \\
\hline $\begin{array}{l}\text { Kompetens- och kun- } \\
\text { skapsutveckling }\end{array}$ & 10 & 2 & 8 & 20 \\
\hline Ledarskap & 6 & I & 3 & 10 \\
\hline Samverkansfrågor & 5 & 0 & 5 & 10 \\
\hline Genusfrågor & 2 & 2 & 2 & 6 \\
\hline $\begin{array}{l}\text { Beslutsfattande, utvär- } \\
\text { dering och kontroll }\end{array}$ & 3 & 0 & I & 4 \\
\hline Etikfrågor & 2 & । & । & 4 \\
\hline $\begin{array}{l}\text { Administrativa verktyg } \\
\text { och dess användning }\end{array}$ & 4 & 0 & 0 & 4 \\
\hline Summa & 84 & 28 & 76 & 188 \\
\hline
\end{tabular}


högt. I Tabell 2 redovisas vilka verksamhetsområden som forskningen handlar om.

Organisationsaspekter kan antingen presenteras utifrån teoretiska eller empiriska begrepp. Med tanke på forskningsöversiktens syfte - att hjälpa intresserade av organisationsproblem finna grundtexterna - så presenteras i rapporten ett sökregister som i huvudsak är induktivt, dvs. härlett från rapporterna som ingår i underlaget. Denna indelningsprincip används för enkelhetens skull även här. I Tabell 3 ges en överblick över vilka organisationsteman som är centrala i studierna.

Som framgår av Tabell 3 tar studierna upp ett brett spektrum av frågor som är centrala i organisationsanalys. Det vanligaste temat är effekterna av speciella organisationsstrukturer. Den andra kategorin i tabellen marbetsvillkor och lokala organiseringsprocesser" innefattar studier som inte i första hand tar upp strukturella faktorer men som bedöms vara viktiga för att förstå organisatoriska aspekter på verksamhetslogik och arbetsvillkor i socialt arbete. Den tredje vanligaste kategorin är organisationsreformer och verksamhetsutveckling, och tar upp både inifrånstudier av förändringsprocesser och effektstudier av strukturella organisationsreformer. Förvånansvärt få studier behandlar ledarskapsfrågor inom socialtjänsten och det är särskilt anmärkningsvärt att endast en av ledarskapsstudierna är utförd av forskare med socialt arbete som ämnestillhörighet. Det kan också vara på sin plats att påpeka att hälften av samtliga ledarskapsstudier gäller arbetsledare inom hemtjänsten, och att endast två studier intresserar sig för politiker som ledare inom socialtjänstens område. Detta är särskilt anmärkningsvärt med tanke på att det ofta är politiker som fattar operativa beslut inom t.ex. den sociala barnavården.

\section{Vilken betydelse har organisationen för utförandet av sociala tjänster?}

Ett grundläggande antagande inom organisationsteorin är att sättet på vilket människor organiserar sig påverkar deras beteende och skapar möjligheter att åstadkomma saker som var och en inte kan åstadkomma på egen hand. Frågan om organisationsformens betydelse för produktionen av sociala tjänster berörs i ganska många av de referenser som ingår i forskningsöversikten. De flesta inom den kategorin undersöker organisationens inverkan på någon särskild verksamhetsaspekt, såsom ledarskap (t.ex. Richard 1997), utvärdering (Eriksson \& Karlsson 1990, Johansson 1995) organisatorisk samverkan (t.ex. Boklund 1995, Wikström et al. 1998, Danermark \& Kullberg 1999), strukturinriktat socialt arbete (Denvall 1994, Sund 1999), förändringsarbete (t.ex. Edvardsson-Stiwne 1997, Johansson et al. 2000), lärande (t.ex. Ström 1997), kvalitetsarbete (Larsson 1996, Olsson \& Ingvad 2000) eller forskningsanvändning (Nilsson 1992). Det finns dock några studier som försökt ta ett helhetsgrepp och undersökt de formella/informella betingelserna för såväl personalens beteende som för verksamhetens resultat.

Szebehely (1995) har tagit ett historiskt och strukturellt grepp på hemtjänstens organisation. Enligt Szebehely finns tre olika organisationsmodeller som vuxit 
fram under olika tidsperioder och som medför tre helt olika styrmekanismer för det löpande arbetet; den traditionella hemtjänsten som har sin parallell i hantverkarnas arbete, servicehusmodellen med likheter $\mathrm{i}$ industrins löpande band och slutligen den självstyrande smågruppsmodellen med viss professionalisering och med likheter $i$ industrins självstyrande grupper. Szebehely (1995) visar att det som kanske uppfattas som en utveckling mot ökad rationalitet och professionalism inte med nödvändighet innebär förbättringar för vårdtagarna. Den traditionella modellen är visserligen inte oproblematisk men ger ändå de bästa förutsättningarna för ett tillfredställande möte, såväl ur vårdbiträdenas som ur de gamlas perspektiv.

Även för individ- och familjeomsorgens del finns strukturella analyser av organisationen som visar på bristande överensstämmelse mellan formell struktur och ändamålsenlig arbetsfördelning. Levin (1998) har undersökt vilka faktorer som styr och påverkar arbetsprocessen och utfallet av arbetet inom de särskilda ungdomshemmen (§ 12-hemmen) samt varför organisationen ser ut som den gör. Enligt Levin organiseras inte arbetet i första hand för att rehabilitera unga kriminella utan för att svara upp mot samhällets krav på inspärrning och kontroll. Denna konflikt är ständigt närvarande och handikappar personalen, och den löses aldrig eftersom den reflekterar de grundläggande villkoren för ungdomsvårdsskolan. Ungdomsvårdsskolan som behandlingsorganisation har fått sin legitimitet över flera decennier eftersom den har dolda funktioner och upprätthåller en given social ordning. Frammes (1998) studie av vården för lättare psykiskt sjuka patienter har likheter med Levin (1998), men konflikterna mellan vårdens olika funktioner förefaller vara mer dolda inom sjukhemsvården.

Det finns även liknande analyser av socialbyråer. Enligt Morén (1992) är den organisationsstruktur som används på de flesta socialbyråer inte så problematisk för »livsanpassning" (social service och ekonomiskt bistånd) men direkt olämplig för »livsomgestaltning" (mänskligt bistånd och behandling). Det finns också studier av socialarbetarnas "verktyg" - telefon, blanketter, texter (Cedersund 1992, Kullberg 1994, Billquist 1999) - samt av socialbyråns lokaler och administrativa system (Billquist 1999) och hur dessa på ett omedvetet och oreflekterat sätt styr verksamheten. Människor och problem omvandlas till fall och ärenden för att över huvud taget kunna hanteras av organisationen och dess byråkratiska arbetsformer.

Det finns än så länge få studier om effekter av användningen av marknadsorienterade strukturer och styrsystem inom svenska kommuners socialtjänst. Enligt Blom (1998), som studerat individ- och familjeomsorgens strukturella villkor i en beställare/-utförarorganisation, har reformen positiva effekter för resursstarka klienter som kunnat ta för sig bland de ökade valmöjligheterna. För mindre resursstarka klienter tycks effekterna vara i huvudsak negativa.

Det är svårt att på några sidor sammanfatta intrycken av ett stort antal organisationsstudier som rör svensk socialtjänst. Ganska många studier undersöker betydelsen av mer informella strukturer, eller betydelsen av olika slags artefakter som är 
vanligt förekommande inom socialtjänsten. Sociologen Monika Nordström (1998) har i sin nyinstitutionella analys av hemtjänsten som organisation liknat den vid ett timglas. Det finns stort utrymme för omsorgstänkande på den politiska nivån. Detta utrymme stramas sedan åt på förvaltningsnivå som mer präglas av ekonomisk rationalitet, för att sedan vidgas i det personliga mötet mellan personal och omsorgstagare. Hemtjänsten är alltså en löst kopplad organisation; de skilda organisationsnivåerna fungerar delvis autonomt och utifrån sina egna betingelser. Normer och värderingar som berör vardagens organisering styr i hög grad det praktiska omsorgsarbetet, medan ideologier och trender på samhällsnivån styr hemtjänstens formella organisering. Modellen liknar i hög grad den s.k. domänteori som utvecklats av Kouzes och Mico (1979) som beskrivningsspråk för välfärdssektorns organisationer. Enligt domänteorin består dessa organisationer av tre skilda domäner - policydomän, administrativ domän och servicedomän - med skilda och motstridiga organisationsprinciper, arbetsmetoder och framgångskriterier. Modellen tycks ha stor giltighet för den svenska socialtjänsten som organisation av forskningsöversikten att döma. De utvalda exemplena visar på att organisationsanalysen har sin givna plats vid studium av socialtjänstens organisatoriska betingelser, arbetsprocesser och resultat.

\section{Vilken betydelse har regiformen för utförandet av sociala tjänster?}

Diskussionen om och förekomsten av alter- nativa regiformer och privatisering inom den sociala sektorn i Sverige är av förhållandevis sent datum. Det har förvisso sedan länge funnits en ideell sektor som av tradition haft en stark position inom missbrukarvården och som samhällspolitisk aktör (Lundström \& Wijkström 1997), men i övrigt har det tagits för givet att socialtjänstverksamhet drivs och finansieras av staten och kommunerna. Förhållandena har dock förändrats tämligen radikalt under 1990-talet. Den privatproducerade vårdens och omsorgens andel av de totala kostnaderna ökade från ca 5 procent 1995 till närmare 10 procent för år 2000. Sammanlagt köpte kommunerna välfärdstjänster för 26 miljarder kronor under år 2000 (SCB 2002). Det är alltså forskningen om verksamheter som drivs i annan regi än offentlig, men som i huvudsak finansieras av offentliga medel, som står i fokus för detta avsnitt. Forskning om kommuner som infört företagsmodeller för sin interna styrning eller socialvård och omsorg som till fullo både drivs och finansieras av privata aktörer ingår inte.

Som beskrivits tidigare i artikeln finns en hel del forskning om den ideella sektorns roll i välfärden och dess relation till den offentliga sektorn (för en översikt se Lundström \& Wijkström 1997, eller Wijkström \& Lundström 2002). Stenius (1999) har studerat arbetsfördelningen inom alkoholistvården mellan offentliga, ideella och privata organisationer under förra seklet. Stenius visar på en arbetsfördelning där den ideella sektorn till en början hade en stor produktionsandel men som minskade fram till och med 1970-talet, för att återigen ha ökat. De förändringar som skett sedan 1980-talet är alltså inte särskilt anmärkningsvärda

Staffan Johansson: Socialtjänstens organisation som forskningsobjekt. 
sedda i ett längre perspektiv. Relationerna mellan den offentliga och den ideella sektorn tycks dock ha förändrats på ett avgörande sätt sedan mitten av 80-talet. Sedan dess råder ett slags kontraktskultur där de ideella organisationerna betraktas som tillhörande en annan samhällssektor än stat och kommun, som vårdgivare jämställs de ofta med bolag och privatpersoner. Den nya kontraktskulturen har passat särskilt väl för Anonyma Alkoholister (AA) som sedan tidigare haft sådana relationer med företag och försäkringsbolag. Stenius fallstudier från fyra kommuner och deras relationer med ett antal fristående vårdproducenter visar dock att inställningen till marknadstänkandet är pragmatiskt bland politikerna, men innebär en tydlig ekonomisering av socialpolitiken. Vid målkonflikter mellan ekonomiska restriktioner och sociala mål gäller alltid ekonomin. De ideella organisationerna har numera ingen särställning utan uppfattas som icke-offentliga institutioner. Fortfarande gäller goda relationer, men det har blivit mer konkurrens mellan icke-offentliga vårdproducenter (Stenius 1999).

Det finns också några avhandlingar som studerar enskilda ideella organisationer som varit verksamma som klientorganisationer och som på ett tydligt sätt beskriver relationerna till offentliga organisationer - för Anonyma Alkoholister se BergmarkHelmersson (1995), för Länkarna se Kurube (1997) - dock utan att på ett systematiskt sätt jämföra regiformerna med varandra. Det huvudsakliga skälet till att det inte har varit aktuellt att jämföra offentliga och ideella regiformer i termer av arbetsprocesser och resultat torde vara att de ideella organi- sationerna har betraktats som komplement och inte som konkurrenter till den offentliga sektorn.

Det finns inom ramen för forskningsöversikten få analyser av regiformens betydelse för utförandet av sociala tjänster som är relaterade till de marknadsreformer (i linje med New Public Management) som öppnat för icke-offentliga vårdproducenter. Enligt Wahlgren (1996), som har jämfört förutsättningarna för kunskapsutveckling i offentliga, privata respektive ideella vårdföretag, tycks driftsformen inte ha någon betydelse för vare sig företagens inre organisation eller för kunskapsutvecklingen bland personalen. Däremot pekar studier av införandet av kundvals-/vouchermodeller på tydligare konsekvenser för såväl organisationen som vårdtagarna. Möller (1997) har analyserat medborgarnas möjlighet att påverka de offentliga tjänsternas utformning inom barnomsorg och äldreomsorg. Studien visar att förutsättningarna för brukarinflytande är olika inom de båda verksamhetsområdena. Inom äldreomsorgen är det betydligt svårare än inom barnomsorgen att agera med de s.k. voice- och exitstrategierna som modellen bygger på.

Effekterna av vouchersystem har också studerats inom handikappområdet. Norén (2000) har analyserat hur en marknad för fristående utförare för personlig assistans vuxit fram som följd av lagen om stöd och service till vissa funktionshindrade (LSS) som trädde i kraft 1994. I studien beskrivs förutsättningarna för den marknad som etablerats och förklaringar ges till hur kvalitetsnivån och valfrihet har kunnat upprätthållas. I studien framkom att det har uppstått två skilda servicekoncept där de 
alternativa producenternas koncept skiljer sig från de mer traditionella kvalitetskriterier som utvecklats inom offentlig sektor.

\section{Slutsatser och implikationer}

Det är viktigt att påpeka att forskningsgenomgången inte är fullständigt heltäckande och inte inkluderar forskning som genomförts efter år 2000. Trots detta ger den anledning att dra slutsatsen att forskningen om socialtjänstens organisation ännu är begränsad, men att det finns en del att lära i redan genomförd forskning. Dellgran och Höjer (2000) beskriver i sin avhandling socialt arbete som ett ungt ämne och dess karaktär som ett "ruralt landskap med begynnande tätortstillväxt». Denna karakteristik verkar gälla även för forskningen om socialtjänsten som organisation mer generellt. Genomgången ger en brokig bild av den svenska forskningen i termer av ämnen, problemställningar, teoretiska fokus, datainsamlingsmetoder och resultat. Den visar att socialtjänstens organisation har stor betydelse för förutsättningarna att producera sociala tjänster, men också att det behövs mer forskning bl.a. om regiformens betydelse. En viktig uppgift för oss som sysslar med denna typ av forskning är att visa kollegor, finansiärer och allmänheten på områdets stora potential. Det är glädjande och hoppingivande att organisationsfrågor på ett tydligt sätt knyts an till frågan om en kunskapsbaserad socialtjänst (Socialstyrelsen 2004).

Det är, för det första, viktigt att ta tillvara på genomförd forskning - "tätorterna" - när nya forskningsområden och nya forsknings- projekt identifieras. Forskningsöversikten har visat att det finns en del forskning om organisationens påverkan på arbetsvillkoren inom socialtjänsten och att det finns studier inom angränsande fält inom välfärdsområdet som kan ligga till grund för fortsatta studier. Vidare finns det en del genomförd forskning om organisationsreformer, om organisationssamverkan och om enskilda ideella organisationers villkor som är värd att bygga vidare på. Det är emellertid angeläget att öka den organisationsteoretiska medvetenheten bland forskarna. Under arbetet med att sammanställa forskningsöversikten slogs jag ofta av hur outvecklad organisationsförståelsen var bland många forskare. Många verkar ha svårt att inse att utrednings- och behandlingsmetoder inte kan avgränsas från organisationsfrågor. Som om en metod som förutsätter ömsesidigt förtroende eller kommunikation skulle kunna avgränsas från det strukturella arrangemang som den ingår i. Organisationsteorin är stadd i snabb utveckling och har mycket att erbjuda för den som vill förstå samhälleliga fenomen i historien och i samtiden. Med en ökad teoretisk medvetenhet följer möjlighet till metodmässig förnyelse vid studier av organisationer.

För det andra behövs fler empiriska studier; det är angeläget att få till stånd fler jämförande studier, inte bara av olika regiformers betydelse, utan också mellan olika kommuners socialtjänst. Det finns indikationer på att olika organisationsmodeller, olika storlek på kommuner, och inte minst olika lokala kulturella traditioner, har stor betydelse för handlingsfrihet, delegering och professionalisering, och som därför starkt påverkar de sociala tjänsternas 
utformning. Forskningsöversikten har också visat på att det också kan vara fruktbart att jämföra socialtjänsten med andra organisationer inom välfärdssektorn, t.ex. skolan och sjukvården, och därvidlag söka förklaringar till olika grad av framgång i professionaliseringssträvanden. De samverkansprojekt som pågår och som också är föremål för forskning väcker sådana frågor.

Det finns också behov att jämföra socialtjänstens organisering mellan olika länder och olika välfärdspolitiska modeller (Esping-Andersen 1990). Medlemskapet i EU driver sannolikt fram homogenisering inom socialpolitiken, och för närvarande utvecklas transnationella koncept inom socialtjänsten (t.ex. LACS inom den sociala barnavården) som implementeras i olika länder (Nygren 2003). Det finns indikationer på att nationella skillnader med avseende på sociallagstiftning, socialpolitik och socialtjänstens organisering undervärderas i dessa implementeringsförsök.

Det är vanligt bland svenska forskare att använda internationella (läs amerikanska) teorier och beskrivningsspråk om Human Service Organizations (Hasenfeld 1982) och Street Level Bureacracies (Lipsky 1980) vid analys av socialtjänstens organisationer. En fråga man kan ställa sig är om, och i så fall i vilken grad, sådana modeller är tilllämpliga på svenska förhållanden, eller om det behövs analysmodeller som ligger närmare den svenska välfärdsmodellen. Utan tvekan finns stora likheter i det sociala arbetets generella karaktär men det finns också olikheter. Den svenska, och för all del också den skandinaviska, välfärdsmodellen är annorlunda än den amerikanska. En stor skillnad mellan Sverige och USA märks i sociallagstiftningens och det juridiska systemets karaktär. En annan skillnad är att svenska vård- och omsorgsorganisationer är mer transparenta, dvs. öppna för offentlig granskning, jämfört med i många andra länder. Även detta förhållande har stor betydelse för det operativa arbetet. En ytterligare skillnad är, som tidigare nämnts, att det politiska inflytandet över den svenska socialtjänsten finns både på strategisk och på operativ nivå. I den internationella teoribildningen saknas ofta lokala politiker och lokal socialpolitik. Det kanske är därför politiker ofta glöms bort vid empiriska studier i Sverige. En annan skillnad är förutsättningarna för organisatorisk samverkan som givetvis är olika inom en kommunal förvaltning och mellan fristående ideella organisationer. Det är därför angeläget att utveckla teoretisk kunskap om socialtjänsten som organisation som är kopplad till olika välfärdsmodeller.

För det tredje skulle forskningsområdet gynnas av mer utvecklad samverkan mellan olika ämnen och discipliner. Kouzes och Mico (1979) använder begreppet Rashomon-effekten för att beskriva problemet att få till stånd mer samsyn inom Human Service Organizations. Begreppet knyter an till Kurosawas film Rashomon där ett antal personer ger helt olika redogörelser för en viss händelse. Frågan är om forskningen om socialtjänsten som organisation också kan betecknas som en Rashomon-effekt, dvs. att olika forskningsdiscipliner berättar olika historier om socialtjänsten och har svårt att förstå varandras berättelser. Det är förvisso naturligt att olika ämnen och discipliner behandlar olika problemområden. För socialt arbete är det naturligt med fokus 
på relationen mellan personal och klient, för sociologen kan fokus ligga på relationen mellan organisation och samhälle, för statsvetaren mellan politik och förvaltning, för företagsekonomen mellan ledning och personal, för psykologen mellan individ och organisation, osv. Med risk för att kasta sten i glashus är det viktigt att påpeka att inget ämne har monopol på sina forskningsobjekt och att det ibland kan vara välgörande för oss forskare att gå över ån efter vatten. Om man vill förstå undflyende fenomen som "organisation" är det angeläget att många perspektiv möts och befruktar varandra.

\section{Referenser}

Bergmark-Helmersson, Karin (1995) Anonyma alkoholister i Sverige. Stockholm: Almkvist \& Wiksell.

Billquist, Leila (1999) Rummet, mötet och ritualerna - en studie av socialbyrån, klientarbetet och klientskapet. Göteborg: Göteborgs universitet, institutionen för socialt arbete, $\mathrm{Nr}$ 4/1999.

Blom, Björn (1998) Marknadsorientering av socialtjänstens individ- och familjeomsorg. Umeå: Umeå universitet, Social Work Studies 27.

Boklund, Ann (1995) Olikheter som berikar? Möjligheter och hinder $i$ samarbetet mellan socialtjänstens äldre- och handikappomsorg, barnomsorg samt individ- och familjeomsorg. Stockholm: Stockholms universitet, Rapport i socialt arbete $\mathrm{nr} 71$.

Brunsson, Nils \& Olsen, Johan P. (1997) The Reforming Organization. Bergen: Fagbokforlaget.

Cedersund, Elisabet (1992) Talk, text and institutional order-a study of communication in social welfare bureaucracies. Linköping: Linköpings universitet, Linköping Studies in Art and Science No 78.

Danermark, Bert \& Kullberg, Christian (1999) Samverkan - Välfärdsstatens nya arbetsform. Lund: Studentlitteratur.

DiMaggio, Paul \& Powell, Walter (1991) »The Iron
Cage Revisited: Institutional Isomorphism and Collective Rationality in Organizational Fields». I Di Maggio, Paul \& Powell, Walter (red) The new institutionalism in organizational analysis. The University of Chicago Press.

Dellgran, Peter \& Höjer, Staffan (2000) Kunskapsbildning, akademisering och professionalisering $i$ socialt arbete. Göteborg: Institutionen för socialt arbete.

Denvall, Verner (1994) För samhällets bästa. Socialtjänstens medverkan $i$ samhällsplaneringen. Floda: Zenon.

Edvardsson-Stivne, Elinor (1997) Förändringsprocesser $i$ kommunal organisation: En studie av organisering och meningsskapande i två förvalt ningar. Linköping Studies in Education and Psychology No 52 .

Eriksson, Bengt \& Karlsson, Per-Åke (1990) Utvärderingens roll i socialt arbete. Göteborg: Göteborgs universitet, institutionen för socialt arbete.

Esping-Andersen, Gösta (1990) The Three Worlds of Welfare Capitalism. Cambridge: Polity Press.

Evans Peter, Rueschemeyer Dietrich \& Skocpol Theda (red.) (1985) Bringing the State Back In. Cambridge: Cambridge University Press.

Framme, Gunilla (1998) Lättskötta och följsamma.

Staffan Johansson: Socialtjänstens organisation som forskningsobjekt. 
Tidsbilder av ett sjukhem och dess patienter. Umeå: Boréa.

Gynnerstedt, Kerstin (1993) Etik i hemtjänst - en studie av förvaltnings- och professionsetik. Lund: Studentlitteratur.

Hasenfeld, Yeheskel (1983) Human Service Organizations. Englewood Cliffs: Prentice Hall.

Hasenfeld, Yeheskel (1992) Human Services as Complex Organizations. Newbury Park, Calif.: Sage.

Hood, Christopher (1995) »The 'New Public Management' in the 1980s: Variations on the Theme" Accounting Organizations and Society, Vol 20, No 2/3, pp 93-109.

Johansson, Staffan (1995) Verksamhetsbedömning $i$ mjuka organisationer. Göteborg: CEFOS.

Johansson Staffan, Löfström Mikael \& Ohlsson Östen (2000) Projekt som förändringsstrategi - analys av utvecklingsprojekt inom socialtjänsten. Stockholm: SNS förlag.

Johansson, Staffan (2002) Socialtjänsten som organisation. Stockholm: Socialstyrelsen.

Johansson, Roine (1998) „Forskning om välfärdsstatens organisation». Lindkvist, Rafael (red.) (1998) Organisation och välfärdsstat. Lund: Studentlitteratur.

Johansson, Vicki (1997) Vem gör vad, när och var? Omsorgens organiseringsformer $i$ kommunerna och kvinnor och mäns omsorgsarbetsdelning. Stockholm: Publica.

Kouzes, James \& Mico, Paul (1979) "Domain Theory: An Introduction to Organizational Behavior in Human Service Organizations", The Journal of Applied Behavioral Science, Vol 15, No 4: 449-469.

Kullberg, Christian (1994) Socialt arbete som kommunikativ praktik. Linköping: Tema kommunikation.

Kurube, Norike (1997) Självhjälp och överlevnaden studie av Länkarna. Stockholm: Stockholms universitet, institutionen för socialt arbete.

Larsson, Patrik (1996) Hemtjänsten ur tre perspektiv. En studie blandäldre, anställda och ledning. Göteborgs universitet: Sociologiska institutionen.

Lawrence, Paul R \& Lorsch, Jay W (1967) Organization and Environment. Boston, Mass: Harvard University Press.
Levin, Claes (1998) Uppfostringsanstalten - Om tvång i föräldrars ställe. Lund: Arkiv Förlag.

Lipsky, Michael (1980) Street Level Bureaucracy. New York: Sage.

Lundström, Tommy \& Wijkström, Filip (1997) The nonprofit sector in Sweden. Manchester: Manchester University Press.

Mayo, Elton (1945) The Social Problems of an Industrial Civilisation. Boston: Harvard University, Graduate School of Business Administration.

Meyer, John \& Rowan, Brian (1977) »Institutionalized Organizations: Formal Structures as Myth and Ceremony" American Journal of Sociology 83: 340-363.

Mizruchi, Mark \& Fein, Lisa (1999) »The Social Construction of Organizational Knowledge: A Study of the Uses of Coercive, Mimetic, and Normative Isomorphism" Administrative Science Quarterly, 44: 653-683.

Morén, Stefan (1992) Förändringens gestalt - Om villkoren för mänskligt bistånd. Stockholm: Publica.

Möller, Tommy (1997) „Mötet med välfärdsstaten - Om exit-strategins begränsningar». Котmunal ekonomi och politik. Volym 1: Nummer 1.

Nilsson, Kjell (1992) Policy, interest and power. Studies in Strategies of Research Utilization. Lund: Meddelanden från Socialhögskolan 1992:1.

Nordström, Monica (1998) Yttre villkor och inre möten - Hemtjänsten som organisation. Göteborg: Göteborgs universitet, Monograph from the Department of Sociology, No 68.

Norén, Lars (2000) "Offentliga marknader och brukarinflytande« Kommunal ekonomi och politik. Volym 2: Nummer 2.

Nygren, Lennart (2003) Barns behov och samhällets insatser. En jämförande studie i fyra länder av implementeringen av ett nytt angreppssätt $i$ den sociala barnavården. Projektansökan till FAS.

Olsson, Eric \& Ingvad, Bengt (2000) Köp, sälj och platta till! Organisationsförändringar, arbetsmiljö och omsorgskvalitet $i$ hemtjänsten under 1990-talet. Lund: Meddelanden från Socialhögskolan 2000:7.

Papakostas, Apostolis (1999) „Recension av Rafael Lindkvists antologi Organisation och välfärdsstatu. Socialvetenskaplig Tidskrift $\mathrm{nr}$ 3/1999. 
Pfeffer, Jeffrey \& Salancik, GeraldR. (1978) The External Control of Organizations: A Resource Dependence Perspective. New York: Harper \& Row.

Pressman, Jeffrey \& Wildavsky, Aaron (1973) Implementation. Berkeley: University of Carlifornia Press.

Richard, Elvi (1997) I första linjen. Arbetsledares mellanställning, kluvenhet och handlingsstrategier i tre organisationer. Lund: Lund Dissertations in Sociology 19

Roethlisberger, Fritz Jules \& Dickson, Wiliam J. (1943) Management and the Worker. Cambridge, Mass: Harvard University Press.

Rothstein, Bo (red.) (1991) Politik som organisation - Förvaltningspolitikens grundproblem. Stockholm: SNS.

Rothstein, Bo (2003) Sociala fällor och tillitens problem. Stockholm: SNS.

SCB (2002) Välfärdsbulletinen $\mathrm{Nr} 2$.

Sahlin-Andersson, Kerstin (1994) „Varför låter sig organisationer omvandlas? «. I Jacobsson, Bengt (red.) Organisationsexperiment ikommuner och landsting. Stockholm: Nerenius \& Santerus.

Scott, W. Richard (1991) Organizations - Rational, natural and opens systems. Englewood Cliffs, N.J: Prentice Hall.

Socialstyrelsen (2004) För en kunskapsbaserd socialtjänst. Slutrapport.
Stenius, Kerstin (1999) Privat och offentligt i svensk alkoholistvård-arbetsfördelning, samverkan och styrning under 1900-talet. Lund: Arkiv Förlag.

Ström, Peter (1997) Förändringsarbete och lärande. Om utveckling av förändringspraktik bland vårdbiträden $i$ hemtjänsten. Lund: Lund University Press, Lund Studies in Education 4

Sund, Kenneth (1999) Socialtjänstens struktur inriktade arbete - utveckling, möjligheter och hinder. Stockholm: Stockholms universitet, institutionen för socialt arbete.

Szebehely, Marta (1995) Vardagens organisering - Om vårdbiträden och gamla i hemtjänsten. Lund: Arkiv.

Wahlgren, Ingela (1996) Vem tröstar Ruth? En studie av alternativa driftsformer $i$ hemtjänsten. Stockholm: Stockholms universitet, företagsekonomiska institutionen.

Weber, Max (1922/1983) Ekonomi och samhälle. Lund: Argos.

Wijkström, Filip \& Lundström, Tommy (2002) Den ideella sektorn: Organisationerna $i$ det civila samhället. Stockholm: Sober Förlag.

Wikström Ewa, Löfström Mikael, Jansson Lennart, Muhlenbock Ylva \& Siverbo Sven (1998) Flerpartssamverkan i missbruksvården. Göteborg: BAS.

Staffan Johansson: Socialtjänstens organisation som forskningsobjekt. 


\section{Summary}

\section{Local welfare organizations as an object for research}

The purpose of the article is to give an overview of Swedish research on the social services in an organizational perspective. The article is empirically based on an overview of doctoral theses, research journals and some other research in different social science disciplines published between 1990 and 2000. The overview shows that the organizational aspect of social service seems to be underestimated by policymakers as well as by social scientists. Nevertheless, there is a bulk of research that evidently shows how the formal and informal organization affects the conditions for operating social service, and that some organization models seem to be counter-productive for improving the situation of the clients.

Although the ideas stemming from New Public Management have influenced Sweden more than most other countries, there is not yet much research on their impact on Swedish social services. Some studies indicate problems related to increased differentiation in the service delivery system while other studies suggest that those reforms have been interpreted by politicians and civil servants in a pragmatic manner and have not affected the social service agencies so much.

The article ends with suggestions for further research. It is suggested that organizational matters should be given more attention among researchers in the field of the social services. It is also important to increase cooperation between researchers from different academic disciplines in order to benefit more from each other and the ongoing research. There is also an increasing need for cross-national comparisons in order to investigate the impact of different social policy and different political traditions on how the social services are organized in different countries. 